\title{
T-Cell Specificity Influences Disease Heterogeneity in Multiple Sclerosis
}

\author{
Carolina Cruciani, PhD,* Marco Puthenparampil, MD, PhD,* Paula Tomas-Ojer, Ivan Jelcic, PhD, \\ Maria Jose Docampo, PhD, Raquel Planas, PhD, Praveena Manogaran, PhD, Roland Opfer, Carla Wicki, PhD, \\ Markus Reindl, PhD, llijas Jelcic, MD, PhD, Andreas Lutterotti, MD, Roland Martin, MD, PhD, and \\ Mireia Sospedra, PhD
}

Neurol Neuroimmunol Neuroinflamm 2021;8:e1075. doi:10.1212/NXI.0000000000001075

\author{
Correspondence \\ Dr. Sospedra \\ mireia.sospedraramos@usz.ch
}

\begin{abstract}
\section{Background and Objectives}

Encouraged by the enormous progress that the identification of specific autoantigens added to the understanding of neurologic autoimmune diseases, we undertook here an in-depth study of $\mathrm{T}$-cell specificities in the autoimmune disease multiple sclerosis (MS), for which the spectrum of responsible autoantigens is not fully defined yet. The identification of target antigens in MS is crucial for therapeutic strategies aimed to induce antigen-specific tolerance. In addition, knowledge of relevant $\mathrm{T}$-cell targets can improve our understanding of disease heterogeneity, a hallmark of MS that complicates clinical management.
\end{abstract}

\section{Methods}

The proliferative response and interferon gamma (IFN- $\gamma$ ) release of CSF-infiltrating $\mathrm{CD} 4^{+} \mathrm{T}$ cells from patients with MS against several autoantigens was used to identify patients with different intrathecal T-cell specificities. Fresh CSF-infiltrating and paired circulating lymphocytes in these patients were characterized in depth by ex vivo immunophenotyping and transcriptome analysis of relevant T-cell subsets. Further examination of these patients included CSF markers of inflammation and neurodegeneration and a detailed characterization with respect to demographic, clinical, and MRI features.

\section{Results}

By testing CSF-infiltrating $\mathrm{CD} 4^{+} \mathrm{T}$ cells from 105 patients with MS against seven long-known myelin and five recently described GDP-L-fucose synthase peptides, we identified GDP-L-fucose synthase and myelin oligodendrocyte glycoprotein (35-55) responder patients. Immunophenotyping of CSF and paired blood samples in these patients revealed a significant expansion of an effector memory $\left(\mathrm{CCR} 7^{-} \mathrm{CD} 45 \mathrm{RA}^{-}\right) \mathrm{CD} 27^{-} \mathrm{Th} 1 \mathrm{CD} 4^{+}$cell subset in GDP-L-fucose synthase responders. Subsequent transcriptome analysis of this subset demonstrated expression of Th1 and cytotoxicity-associated genes. Patients with different intrathecal T-cell specificities also differ regarding inflammation- and neurodegeneration-associated biomarkers, imaging findings, expression of HLA class II alleles, and seasonal distribution of the time of the lumbar puncture.

\section{Discussion}

Our observations reveal an association between autoantigen reactivity and features of disease heterogeneity that strongly supports an important role of T-cell specificity in MS pathogenesis. These data have the potential to improve patient classification in clinical practice and to guide the development of antigen-specific tolerization strategies.

\footnotetext{
*These authors contributed equally to this work.

From the Neuroimmunology and MS Research (NIMS) (C.C., M.P., P.T.O., I.J., M.J.D., R.P., P.M., C.W., I..., A.L., R.M., M.S.), Department of Neurology, University Hospital and University Zurich, Switzerland; Department of Neuroscience DNS (M.P.), University-Hospital of Padova, Italy; Jung Diagnostics GmbH (R.O.), HIP - Health Innovation Port, Germany; Department of Health Sciences and Technology (C.W.), ETH Zurich, Switzerland; and Clinical Department of Neurology (M.R.), Medical University of Innsbruck, Austria.

Go to Neurology.org/NN for full disclosures. Funding information is provided at the end of the article.

The Article Processing Charge was funded by the authors.
}

This is an open access article distributed under the terms of the Creative Commons Attribution-NonCommercial-NoDerivatives License 4.0 (CC BY-NC-ND), which permits downloading and sharing the work provided it is properly cited. The work cannot be changed in any way or used commercially without permission from the journal. 


\section{Glossary}

CP = control patient; EM = effector memory; FLAIR = fluid-attenuated inversion recovery; GDP-L-FS = GDP-L-fucose synthase; HD = healthy donor; HLA = human leukocyte antigen; IFN = interferon; IgG = immunoglobulin G; $\mathbf{M B P}=$ myelin basic protein; LP = lumbar puncture; MOG = myelin oligodendrocyte glycoprotein; MOGAD = myelin oligodendrocyte glycoprotein antibody-associated disease; MPRAGE = Magnetization Prepared - RApid Gradient Echo; MS = multiple sclerosis; PBMC = peripheral blood mononuclear cell; RA = rheumatoid arthritis; $\mathbf{S I}=$ stimulation index; $\mathbf{T F}=$ transcription factor.

Multiple sclerosis (MS) is considered an immune-mediated demyelinating disease of the CNS. ${ }^{1}$ There is general agreement about the relevance of $\mathrm{B}$ cells, ${ }^{2} \mathrm{CD}^{+} \mathrm{T}$ cells, ${ }^{3,4}$ and particularly $\mathrm{CD}^{+} \mathrm{T}$ cells in MS pathogenesis. However, despite the fact that myelin-specific $\mathrm{CD} 4^{+} \mathrm{T}$ cells can exacerbate $\mathrm{MS}^{5}$ and that specific $\mathrm{T}$ cells can induce disease in different animal models of $\mathrm{MS},{ }^{6,7}$ there is less consensus about the relevance of $\mathrm{CD}^{+}$ T-cell specificity.

Disease heterogeneity is a hallmark of MS and likely stems from the interplay of a complex genetic background ${ }^{8,9}$ and environmental risk factors. ${ }^{10}$ Although it is well described that disease heterogeneity encompasses composition of tissue lesions, imaging findings, clinical presentation, disease course, and treatment responsiveness, the factors contributing to this heterogeneity, including a putative involvement of $\mathrm{T}$-cell specificity, are not clear. From studies in Experimental Autoimmune Encephalomyelitis (EAE), the most commonly used animal model in MS, ${ }^{6,11}$ it is well known that both the rodent strain, i.e., the genetic background, and the antigen used to induce EAE influence disease course, severity, lesion distribution, and pathologic mechanisms, ${ }^{7,12,13}$ linking T-cell specificity and disease heterogeneity.

The identification of the target antigens in neurologic autoimmune diseases ${ }^{14-16}$ has led to great progress in understanding, diagnosing, and treating these diseases. To better understand and treat MS, researchers have investigated $\mathrm{CD} 4^{+}$ T-cell specificity for years, albeit with less success than expected. The difficulties in obtaining CNS-infiltrating $\mathrm{CD}^{+} \mathrm{T}$ cells, the overall low antigen avidity of self-antigen-reactive $\mathrm{T}$ cells, and the limited information about $\mathrm{T}$ cell-specific autoantigens in MS have hampered research progress. In addition to the long-known myelin peptides, ${ }^{17}$ few $\mathrm{T}$ cell-specific autoantigens have been identified so far. We recently identified GDP-L-fucose synthase (GDP-L-FS)-derived peptides as putative autoantigens in human leukocyte antigen (HLA)-DRB3* patients with MS. ${ }^{18}$

To evaluate the relevance of $\mathrm{CD} 4^{+} \mathrm{T}$-cell specificity in MS, we studied their link with features of disease heterogeneity. We identified patients with different CSF-infiltrating $\mathrm{CD} 4^{+} \mathrm{T}$-cell responses against myelin and GDP-L-FS peptides and characterized them by ex vivo immunophenotyping of CSF and paired blood samples as well as with respect to demographic, clinical, and MRI features.

\section{Methods}

\section{Patient Samples}

Paired CSF and blood samples were collected from 105 untreated patients with MS, only CSF from 11 control patients (CPs), and 10 patients with myelin oligodendrocyte glycoprotein antibody-associated disease (MOGAD) negative for anti-AQP4 antibodies and only peripheral blood mononuclear cells (PBMCs) from four healthy donors (HDs) (eTable 1, links.lww.com/NXI/A590). Eighty-four patients with MS (80\%) had never been treated, whereas 21 (20\%) were previously treated but considered untreated at the time of lumbar puncture (eTable 1, links.lww.com/NXI/A590). Patients and controls were recruited from the NIMSNeuroimmunology and MS Research Section, Department of Neurology, University Hospital Zurich. MS diagnosis was based on the revised McDonald criteria. ${ }^{19}$

\section{Standard Protocol Approvals, Registrations, and Patient Consents}

The Cantonal Ethics Committee of Zurich approved the study procedures (EC-No. 2013-0001). Informed consent was obtained from all patients.

\section{CSF and Serum Measures}

Albumin quotients and CSF-specific oligoclonal bands were analyzed as previously reported. ${ }^{20}$ Intrathecal Ig synthesis (Ig [loc]) was calculated according to Reiber. ${ }^{21}$

\section{Cell Culture and Stimulation}

PBMCs were freshly isolated using Ficoll (Eurobio, Germany) density-gradient centrifugation. CSF-infiltrating $\mathrm{CD}^{+} \mathrm{T}$ cells were expanded with phytohaemagglutinin in a single round of stimulation using a previously reported protocol aimed to reduce $\mathrm{T}$ cell receptor repertoire bias. ${ }^{18} 6 \times 10^{4}$ phytohaemagglutininexpanded CSF-infiltrating $\mathrm{CD}^{+} \mathrm{T}$ cells were seeded in quadruplicate with $2 \times 10^{5}$ irradiated autologous PBMCs as antigenpresenting cells and stimulated with peptides (eTable 2, links. lww.com/NXI/A590) at a final concentration of $10 \mu \mathrm{M}$ and with a $\mathrm{T}$ Cell Activation Kit (anti-CD3, anti-CD28, and anti-CD2 beads) (Miltenyi Biotec) as positive control.

\section{Proliferative Responses}

We measured proliferation 72 hours after stimulation using 3H-thymidine (Hartmann Analytic, Braunschweig, Germany) as previously reported. ${ }^{18}$ The stimulation index of single wells 
(SI) was calculated as follows: $\mathrm{SI}=(\mathrm{cpm}$ well with peptide $) /$ (Mean cpm wells without peptide). A well was considered positive if $S I \geq 2$. A patient was considered positive for a peptide if the mean SI of the four wells was $\geq 2$ and at least 3 of the four wells showed a SI $\geq 2$.

\section{Quantification of Cytokines}

Release of interferon gamma (IFN- $\gamma$ ) was measured using the ELISA MAX Deluxe Set Human IFN- $\gamma$ (BioLegend, San Diego, CA) according to the manufacturer's instructions. A well was considered positive if IFN- $\gamma \geq 20 \mathrm{pg} / \mathrm{mL}$, and a patient was considered positive for a peptide if the mean IFN- $\gamma$ of the four wells was $\geq 20 \mathrm{pg} / \mathrm{mL}$ and at least 3 of the 4 wells were positive.

Cytokines in supernatants and CSF were measured using the Human T Helper Cytokine Panel LEGENDplex bead-based immunoassay (BioLegend) according to the manufacturer's instructions.

\section{Immunophenotyping}

Ex vivo immunophenotyping of intrathecal and paired circulating lymphocytes was performed as previously reported ${ }^{20,22}$ in a subcohort of 66 patients with MS (eTable 1, links.lww.com/ NXI/A590). We added SPHERO AccuCount Particles (Spherotech, Inc., Lake Forest, IL) to count absolute numbers following the manufacturer's instructions. An LSRFortessa cytometer (BD Biosciences, Franklin Lakes, NJ) was used to acquire samples and FACSDiva (BD) and FlowJo (TreeStar Inc., Ashland, OR) software for the analysis. eFigure 1, links.lww.com/NXI/A590, summarizes the gating strategy.

\section{Sorting of Cell Subsets}

PBMCs from four patients with MS and four age- and sex-matched HDs were labeled with antibodies against CD4 (allophycocyanin), CD45RA (BV711), CCR7 (BV421), CD27 (phycoerythrin), and CD28 (allophycocyanin-Cy7), all from BioLegend and with livedead aqua dye (Invitrogen). $\mathrm{CD}^{+} \mathrm{CCR}^{-} \mathrm{CD}^{-} 5 \mathrm{RA}^{-} \mathrm{CD} 28^{+}$ $\mathrm{CD} 27^{+}$and $\mathrm{CD}^{+}{ }^{+} \mathrm{CCR}^{-} \mathrm{CD}^{-} 5 \mathrm{RA}^{-} \mathrm{CD} 28^{+} \mathrm{CD} 27^{-}$live cells were sorted using $100-\mu \mathrm{m}$ sorting chips in a Sony SH800SFP cell sorter (4 lasers, Sony). Twenty thousand sorted cells from each cell population were transferred to an RNase-free tube, resuspended in Qiazol (Qiagen, Germany), and frozen at $-80^{\circ} \mathrm{C}$.

\section{RNA Extraction, Sequencing, and Analysis}

RNA extraction from frozen cell pellets was performed using the PicoPure RNA Isolation Kit (Life Technologies) according to the manufacturer's instruction. RNA sequencing (RNAseq) was performed using Illumina Sequencing 200M at the Functional Genomics Center Zurich as previously reported. $^{23}$ The RNAseq data analysis consisted of (1) cleaning of raw reads using Trimmomatic (version 0.36$)^{24}$; (2) pseudoalignment of sequences to the human reference genome (build GRCh38.p13, gene annotation from GENCODE Release 32) and gene expression quantification using Kallisto (version 0.44$)^{25}$; (3) read alignment using STAR $(\mathrm{v} 2.7 .3)^{26}$; and (4) differentially expressed gene detection using a count-based negative binomial model implemented in the software package EdgeR (R version: 3.6.1, EdgeR version: 3.28.0). ${ }^{27}$ We used a generalized linear model adapted for overdispersed data to assess differential expression. Genes showing $p$ value $<0.001$ for altered expression were considered differentially expressed.

\section{Enzyme-Linked Immunosorbent Assays}

The following proteins were quantified using enzyme-linked immunosorbent assay kits: neurofilament light chain (NfL) (Human Diagnostics, Umea, Sweden); CXCL13/BLC/BCA1, granzyme $A$, and granulysin (R\&D System, $M N$ ); chitinase 3 like 1 (MicroVue, Athens, $\mathrm{OH}$ ); perforin, granzyme $\mathrm{B}$, and granzyme $\mathrm{H}$ (Invitrogen-Thermo Fisher Scientific, MA), were used according to the manufacturer's instructions.

\section{HLA Typing}

Patients were typed for HLA-class I $\left(\mathrm{A}^{*}\right.$ and $\left.\mathrm{B}^{*}\right)$ and HLA class II (DRB1* ${ }^{*} \mathrm{DRB}^{*}, \mathrm{DRB} 4^{*}, \mathrm{DRB} 5^{*}, \mathrm{DQA1}{ }^{*}$, and $\left.\mathrm{DQB1} 1^{*}\right)$ as previously reported. $^{20}$

\section{MOG Antibody Detection Assay}

Serum and CSF samples were analyzed for myelin oligodendrocyte glycoprotein (MOG) immunoglobulin G (IgG) antibodies as described before. ${ }^{28}$ For screening, serum samples were diluted 1:20 and 1:40 and CSF samples 1:2. Positive samples were end point titrated, and MOG-IgG positivity was confirmed using an anti-human $\operatorname{IgG}(\mathrm{Fc})$ specific secondary antibody as recently described. ${ }^{28}$

\section{MRI}

Eight patients were scanned with a 3T Philips Ingenia and 22 patients with 3T Siemens Skyra. The MRI protocol included a 3D pre- and post-gadolinium contrast-enhanced gradient echo pulse sequence (MPRAGE) as well as a 3D fluid-attenuated inversion recovery (FLAIR) sequence.

From FLAIR, the number and the total volume in milliliters of all hyperintense lesions were determined by an automatic algorithm based on convolutional neural networks. ${ }^{29}$ All results were manually corrected by two experienced technical raters. Differences in the corrections were resolved by consensus in a second reading phase. Similarly, the number of contrast-enhancing lesions was determined.

Whole-brain, gray matter, and thalamic volumes in milliliters were determined on the precontrast MPRAGE image using the automatic processing pipeline Biometrica MS analysis platform (version 2.1, jung diagnostics GmbH, Hamburg, Germany). ${ }^{30}$

\section{Statistics}

We used GraphPad Prism 8.0 (GraphPad Software, La Jolla, CA) to perform the statistical analysis. We used the unpaired $t$ test to compare two groups of normally distributed variables and $U$ test (Mann-Whitney) for non-normally distributed variables. For the comparison of more than 2 groups of patients, we used the Kruskal-Wallis test for non-normally distributed variables. We used Spearman $r$ to test the linear 
Table 1 Percentage of Positive Wells and Patients for Each Peptide Using Proliferation and IFN-y Release

\begin{tabular}{|c|c|c|c|c|}
\hline & \multicolumn{2}{|l|}{$\begin{array}{l}\text { Positive wells } \\
\%\end{array}$} & \multicolumn{2}{|c|}{$\begin{array}{l}\text { Positive patients } \\
\%\end{array}$} \\
\hline & Proliferation & IFNy release & Proliferation & IFNy release \\
\hline GDP-L-FS (51-65) & 5.48 & 7.16 & 3.80 & 5.71 \\
\hline GDP-L-FS (136-150) & 7.14 & 8.35 & 5.71 & 7.62 \\
\hline GDP-L-FS (161-175) & 7.38 & 6.92 & 6.66 & 5.71 \\
\hline GDP-L-FS (246-260) & 6.90 & 8.85 & 4.76 & 8.57 \\
\hline GDP-L-FS (296-310) & 6.43 & 12.65 & 4.76 & 11.42 \\
\hline MBP (13-32) & 0.72 & 4.34 & 0.00 & 1.90 \\
\hline MBP (83-99) & 1.92 & 6.28 & 0.96 & 5.71 \\
\hline MBP (111-129) & 1.20 & 6.75 & 0.96 & 4.76 \\
\hline MBP (146-170) & 0.72 & 3.86 & 0.00 & 2.85 \\
\hline MOG (1-20) & 1.20 & 4.58 & 0.00 & 1.90 \\
\hline MOG (35-55) & 3.61 & 13.49 & 1.92 & 12.38 \\
\hline PLP (139-154) & 1.92 & 3.86 & 0.96 & 3.80 \\
\hline CEF & 23.39 & 38.90 & 22.80 & 35.2 \\
\hline
\end{tabular}

Abbreviation: CEF = cytomegalovirus, Epstein-Barr virus and influenza virus; GDP-L-FS = GDP-L-fucose synthase; MBP = myelin basic protein; MOG = myelin oligodendrocyte glycoprotein; PLP = Myelin proteolipid protein.

correlation between non-normally distributed variables. The significance level was set at $p<0.05$. Associations between patient specificity, seasonal distribution of lumbar puncture (LP), and HLA were performed using the Fisher exact test with $5 \%$ significance.

\section{Results}

\section{Identification of GDP-L-FS and Myelin Responders}

Proliferation and IFN- $\gamma$ release of CSF-infiltrating $\mathrm{CD}^{+}$ $T$ cells from 105 patients with MS against 5 immunodominant GDP-L-FS ${ }^{18}$ and 7 myelin peptides ${ }^{31}$ are shown in eFigure $2 \mathrm{~A}$, links.lww.com/NXI/A590. GDP-L-FS peptides induced the highest frequency of positive wells using proliferation as readout and MOG(35-55) peptide using IFN- $\gamma$ release (Table 1). We also analyzed responses to a viral/bacterial peptide pool cytomegalovirus, Epstein-Barr virus and influenza virus (CEF) (eFigure 2A, links.lww.com/NXI/A590, and Table 1). IFN- $\gamma$ secretion identified more positive wells than proliferation for myelin and CEF peptides, but comparable results for GDP-L-FS peptides (eFigure 2B, links.lww.com/NXI/A590). Accordingly, the strongest correlation between proliferation and IFN- $\gamma$ has been found for GDP-L-FS peptides (eFigure 2C, links.lww.com/NXI/A590).

The frequency of patients with positive responses to the different peptides is summarized in Table 1. In 14 patients (13.34\%), the main reactivity in proliferation and/or IFN- $\gamma$ release was against several GDP-L-FS peptides and was classified as GDP-L-FS- responders (Figure 1). Among these, 6 patients (42.8\%) showed also positive responses to myelin peptides. The association between GDP-L-FS reactivity and reactivity to myelin peptides was significant $(p \leq 0.0001$, Fisher exact test). Four patients (3.8\%) responded only to myelin basic protein (MBP) peptides and were classified as MBP responders, whereas 11 patients (10.4\%), responding only against MOG (35-55), were classified as MOG(35-55) responders. Seventy-six patients (72.4\%) did not react to any autoantigen and were classified as nonresponders (Figure 1). The response to CEF peptides was comparable in the different groups of patients with the exception of MOG(35-55) responders, in whom it was lower (Figure 1). Because of the low number of MBP responders $(<5)$, this group was not analyzed further.

\section{Distinct CSF-Infiltrating and Circulating T Cells in GDP-L-FS Responders}

Immunophenotyping of CSF-infiltrating and circulating lymphocytes was performed in a subcohort of patients with MS (eTable 1, links.lww.com/NXI/A590) consisting in GDP-L-FS $(\mathrm{n}=7), \operatorname{MOG}(35-55)(\mathrm{n}=7)$, and nonresponder $(\mathrm{n}=52)$ patients (eTable 3, links.lww.com/NXI/A590). Effector memory (EM, CCR7 ${ }^{-} \mathrm{CD}^{2} 5 \mathrm{RA}^{-}$) $\mathrm{CD}^{+}{ }^{+} \mathrm{T}$ cells expressing $\mathrm{CD} 28$ but not $\mathrm{CD} 27\left(\mathrm{EM} \mathrm{CD} 27^{-}\right)$were significantly more abundant in the CSF of GDP-L-FS responders (Figure 2, $\mathrm{A}$ and $\mathrm{B}$, and eFigure 3A, links.lww.com/NXI/A590). Among these EM CD27 $7^{-}$cells, only cells with a Th1 $\left(\mathrm{CCR}^{-} \mathrm{CCR}^{-} \mathrm{CRTh}^{-}\right)$ functional phenotype (EM CD27 ${ }^{-}$Th1), showed significantly higher frequencies (Figure 2B and eFigure 3B, links.lww.com/ $\mathrm{NXI} / \mathrm{A590}$ ). Analysis of paired blood samples demonstrated that these cells were also significantly more abundant in frequency and 
Figure 1 Identification of GDP-L-FS and Myelin-Responder Patients
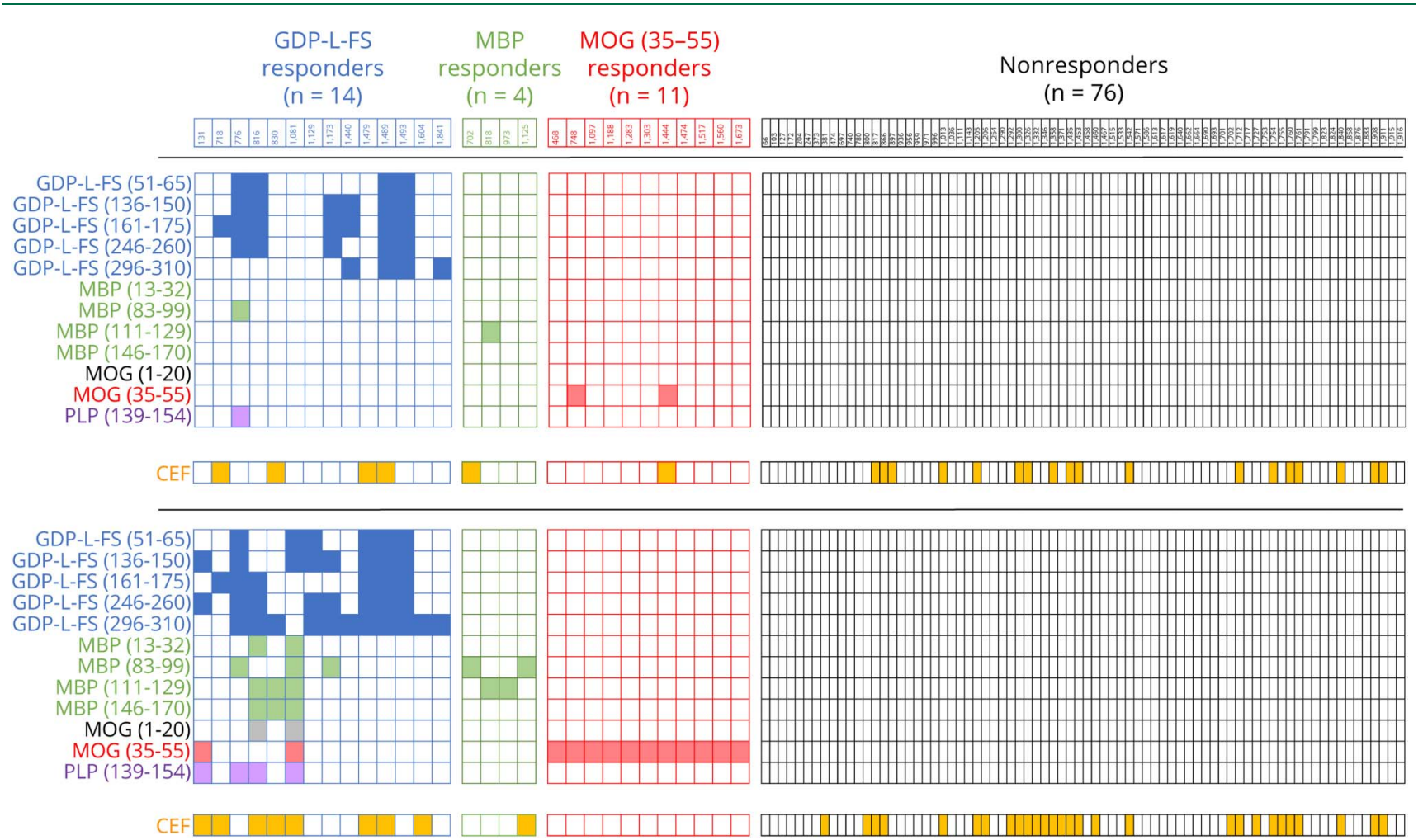

Checkerboard graphs illustrating the response of each patient with MS to the individual peptides. Filled cells are positive responses in proliferation (upper checkerboard graph) and IFN-y release (lower checkerboard graph). The number of GDP-L-FS, MBP, MOG(35-55), and nonresponders is shown in each group. Peptides color code, GDP-L-FS (blue), MBP (green), MOG(1-20) (black), MOG(35-55) (red), Myelin proteolipid protein (PLP) (violet), and CEF (orange). GDP-L-FS = GDP-L-fucose synthase; MS = multiple sclerosis.

absolute counts in the blood (Figure 2, A and C, and eFigure 3C, links.lww.com/NXI/A590). CSF-infiltrating and circulating $\mathrm{CD}^{+}{ }^{+} \mathrm{T}$ cells with a TEMRA $\left(\mathrm{CCR} 7^{-} \mathrm{CD} 45 \mathrm{RA}^{+}\right)$differentiation state and the costimulatory molecules $\mathrm{CD} 28^{+} \mathrm{CD} 27^{-}$and CD28 ${ }^{-}$were also more abundant in GDP-L-FS responders (eFigure 3, A and C, links.lww.com/NXI/A590).

\section{Transcriptional Signatures of EM CD27 ${ }^{-}$CD4 ${ }^{+}$ T Cells in GDP-L-FS Responders}

$\mathrm{EM} \mathrm{CD} 27^{-}$and $\mathrm{CD} 27^{+} \mathrm{CD} 4^{+} \mathrm{T}$ cells were sorted from the peripheral blood of four GDP-L-FS responders (eFigure 4A, links.lww.com/NXI/A590) and the transcriptome analyzed by RNAseq. We identified 265 differentially expressed genes (fold change 1.5, $p<0.001$ ), 119 upregulated and 146 downregulated, in EM CD27 ${ }^{-}$vs EM CD27 ${ }^{+}$cells (Figure $3 \mathrm{~A}$ ). The upregulated genes included (1) transcripts linked to cytotoxic $\mathrm{CD} 8+{ }^{32}$ and $\mathrm{CD} 4+{ }^{33} \mathrm{~T}$ cells such as ADGRG1 (GPR56), ADGRG5 (GPR114), CCL4, CCL5, CST7, CTSW, CX3CR1, ENC1, FCRL6, FGFBP2, GNLY, GZMB, GZMH, MYO6, PRF1, PRSS23, S1PR5, SLAMF7, SPON2, TGFBR3, TRGC2, and ZEB2; (2) transcription factors (TFs) important in the development of cytotoxic $\mathrm{CD}^{+}{ }^{+} \mathrm{T}$ cells such as Eomesodermin (Eomes) ${ }^{34}$ and T-bet (encoded by TBX21) ${ }^{35}$; and (3) other genes associated with Th1 cells such as interferon gamma gene and granzyme A gene (GZMA). In contrast, cytokines, chemokine receptors, and TFs associated with other Th subsets (CCR4, CCR6, IL4R, IL6R, GATA3, and FoxP3) were downregulated in EM CD27 $7^{-}$cells.

We also analyzed the same sorted EM subpopulations from four HDs (eFigure 4A, links.lww.com/NXI/A590). The 265 genes that differentiate EM CD27 ${ }^{-}$and $\mathrm{CD} 27^{+}$cells in GDP-L-FS responders did not discriminate EM subpopulations in $\mathrm{HDs}$ (Figure 3A). Differential gene expression analysis of EM CD27 cells from GDP-L-FS responders and HDs also identified 145 differentially expressed genes (fold change 1.5, $p<0.001$ ), with 66 upregulated in the GDP-L-FS-responders that include 19 genes linked to cytotoxicity and Th1 T cells and 79 downregulated including genes associated with other $\mathrm{T}$-cell subsets (eFigure 4B, links.lww.com/NXI/A590, and Figure 3A).

The transcription of genes characteristically associated with Th1 cells and cytotoxicity (TBX21, GZMA, EOMES, GNLY, GZMH, and SLAMF7) was overall increased, and transcription of genes associated with other Th subsets (GATA3, CCR4, and CCR6) decreased in EM CD27- cells from GDP-L-FS responders compared with the same cells from $\mathrm{HDs}$ and with EM CD27 $7^{+}$cells (Figure 3B).

\section{Characterization of GDP-L-FS- and MOG(35-55)- Specific Responses}

The functional phenotype of GDP-L-FS- and MOG(35-55)specific $\mathrm{CD}^{+} \mathrm{T}$ cells was analyzed in the supernatant of 
A. \% of $\mathrm{CD} 4+\mathrm{EM}$

CSF

Blood
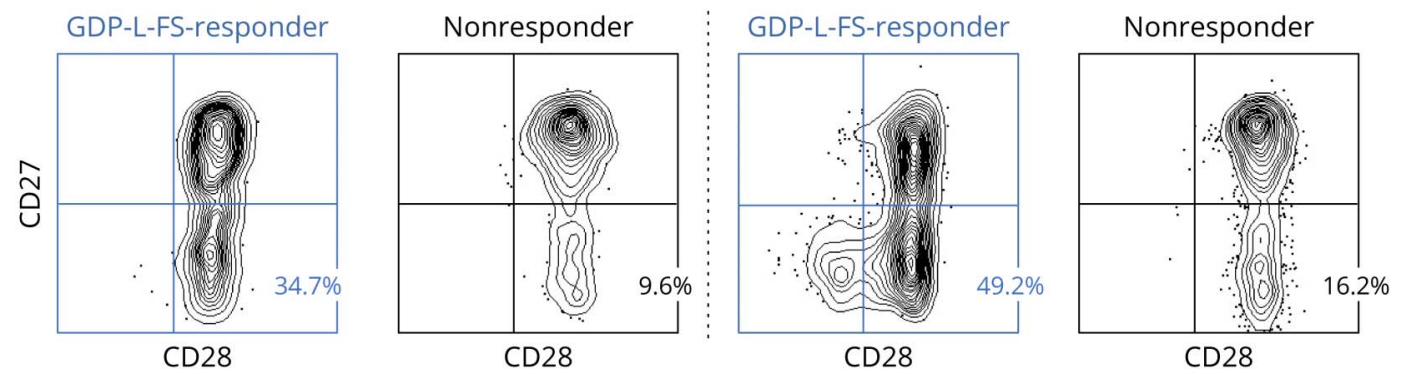

B. CSF

CD4+ EM CD28+ CD27-

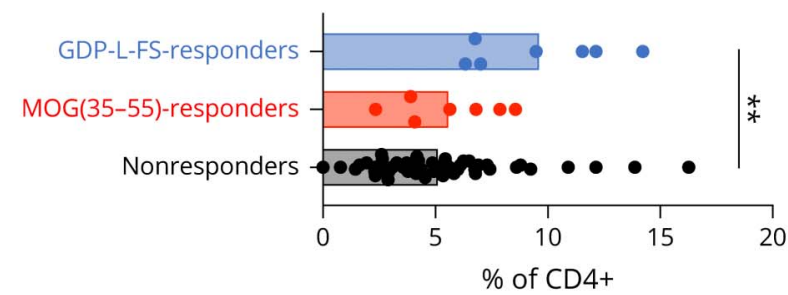

C. Blood

CD4+ EM CD28+ CD27-
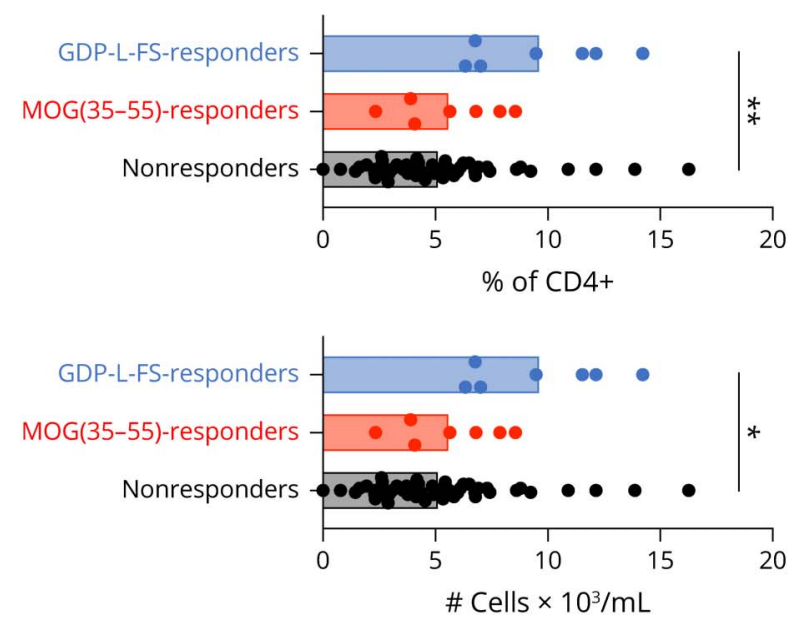

Th1 (CCR6- CCR4- CRTh2-)

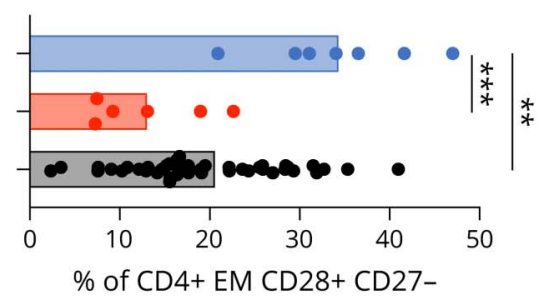

Th1 (CCR6- CCR4- CRTh2-)
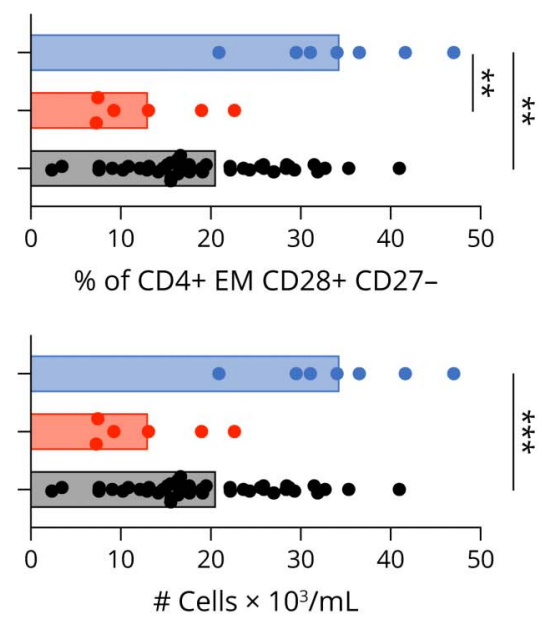

A) Dot plot showing CD28 and CD27 expression on CSF-infiltrating and peripheral circulating EM CD4 ${ }^{+}$cells from GDP-L-FS and nonresponders. Percentages of EM CD27 $7^{-}$cells are shown. (B and C) Frequencies of CSF-infiltrating (B) and frequencies and absolute numbers of peripheral circulating (C) EM CD27 and EM CD27 ${ }^{-}$Th1 cells in GDP-L-FS (blue), MOG(35-55) (red), and nonresponders (black). Cell counts were determined using SPHERO AccuCount Particles. Each dot

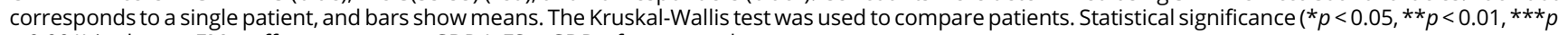
$<0.001$ ) is shown. EM = effector memory; GDP-L-FS = GDP-L-fucose synthase.

positive wells stimulated with the cognate antigen (Figure 4A). GDP-L-FS-specific cells released significantly higher amounts of IL-2 than MOG(35-55)-specific cells. This higher IL-2 is most likely involved in the significantly stronger ability of GDP-L-FS-specific cells to proliferate in response to specific peptides, whereas the proliferation to unspecific stimulating beads was comparable in GDP-L-FSand MOG(35-55)-specific cells (Figure 4B). IFN- $\gamma$ was the main cytokine released by GDP-L-FS-specific cells indicating a Th1 functional phenotype. MOG(35-55)-specific cells, in addition to IFN- $\gamma$, released cytokines associated with other Th subsets (IL-9, IL-6, and IL-10), suggesting a polyfunctional phenotype (Figure 4A). IL-10 also was significantly higher in the CSF of MOG(35-55) responder and Th2-associated cytokines (Figure 4A). Because some of the cytokines released by MOG(35-55)-specific cells have been found elevated in CSF from patients with MOGAD, ${ }^{36}$ and because both groups of patients share the target antigen, we verified that none of the patients with MS had positive anti-MOG IgG titers in serum or CSF (eTable 4, links.lww. com/NXI/A590) and also analyzed the cytokine profile in the CSF from patients with MOGAD (eTable 1 and 


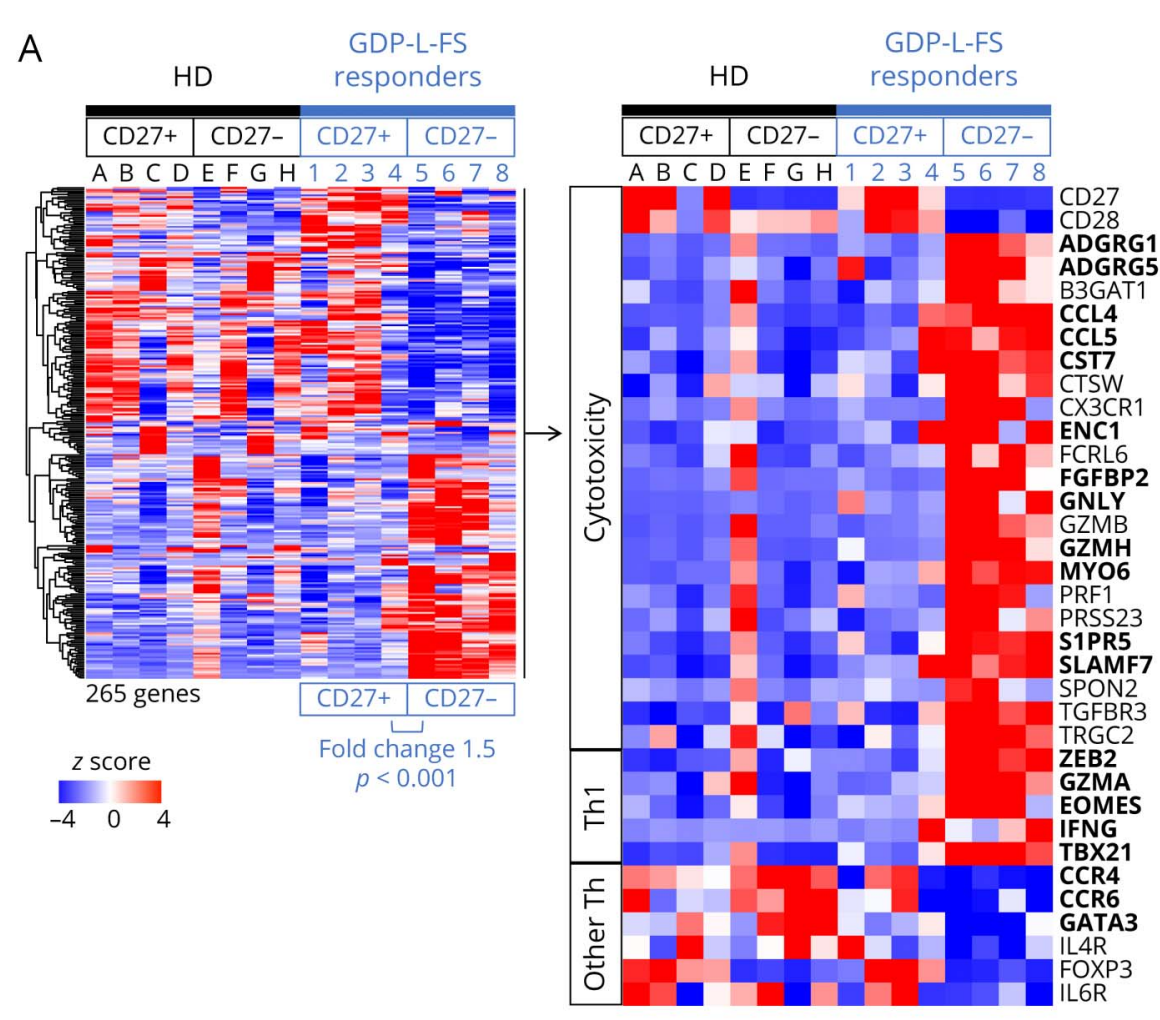

B
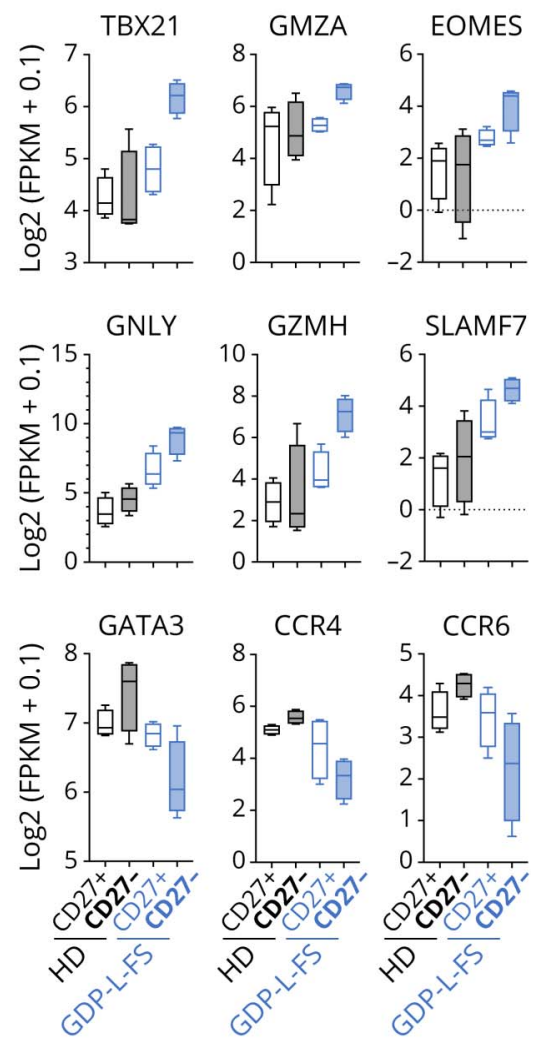

(A) Heat map shows the row-wise z scores of 265 transcripts differentially expressed between EM CD27 ${ }^{+}$(columns 1-4) and EM CD27 (columns 5-8) cells (Log2Ratio $>0.5, p<0.001$ ) from four GDP-L-FS responder patients. Z scores of these genes in EM CD27 ${ }^{+}$(columns A-D) and EM CD27 ${ }^{-}$(columns E-H) cells from HDs are also shown. Z scores of selected genes associated with cytotoxicity, Th1, and other Th subsets are shown in detail. In bold are genes that also were differentially expressed in EM CD27 from GDP-L-FS responders vs EM CD27 from HDs (Log2Ratio $>0.5, p<0.001$ ). (B) Distribution of log2(fragments per kilobase per million + 0.1) gene expression of Th1/cytotoxic genes and genes associated with other Th subsets in EM CD27 ${ }^{+}$and CD27 ${ }^{-}$cells from GDP-L-FS responders and HDs. EM = effector memory; GDP-L-FS = GDP-L-fucose synthase; HDs = healthy donors.

eFigure 5A, links.lww.com/NXI/A590). Although cytokines such as IL-9, IL-22, and IL-6 were high in both groups, the Th2-associated cytokines IL-4 and IL-10 were significantly higher in MOG(35-55) responders (eFigure 5A, links.lww. com/NXI/A590).

Supporting a role of humoral immunity in MOG(35-55) responders, we found significantly higher frequencies of CSF-infiltrating but not circulating naive $\mathrm{B}$ cells in these patients (Figure 4C). The amounts in the CSF of CXCL13 37 were higher in MOG(35-55) responders and chitinase 3 like 1 , a general marker of inflammation, ${ }^{38}$ in GDP-L-FS responders when compared with CPs (eTable 1, links.lww. com/NXI/A590) (eFigure 5B, links.lww.com/NXI/A590). Both groups of patients showed significantly higher intrathecal IgG synthesis than CP (eFigure 5B, links.lww.com/ NXI/A590).

Further CSF analysis of cytotoxic and neurodegenerative markers revealed undetectable amounts of perforin and granzyme B, no significant differences for granulysin, and higher levels of granzyme $\mathrm{H}$, granzyme $\mathrm{A}$, and $\mathrm{NfL}^{39}$ in GDP-L-FS responders (eFigure 5C, links.lww.com/NXI/A590).

\section{Association of GDP-L-FS Reactivity and HLA-DRB3*02:02/03:01}

All patients were HLA typed (eTable 5, links.lww.com/NXI/ A590). Figure 5A summarizes frequencies of GDP-L-FS, MOG(35-55), and nonresponders expressing the MS-associated DR15 haplotype and DRB3*02:02/03:01 alleles. Based on two previously typed MS cohorts (German cohort $[\mathrm{n}=1,270]$ and Swiss cohort $[n=367])$, we expected that $40 \%-50 \%$ of patients with MS express the DR15 haplotype and $30 \%-40 \%$ the DRB3*02: 02/03:01 alleles. The frequency of GDP-L-FS responders expressing the DR15 haplotype (21.4\%) was lower than expected, whereas those expressing the DRB3*02:02/03:01 alleles (92.8\%) were much higher. The association between GDP-L-FS specificity and $\mathrm{DRB3}^{*} 02: 02 / 03: 01$ alleles was significant $(p \leq 0.0001$, Fisher exact test, Figure $5 \mathrm{~A})$, confirming our previous results. ${ }^{18}$

Figure 5B shows CSF-infiltrating $\mathrm{CD}^{+}{ }^{+} \mathrm{T}$-cell responses to GDP-L-FS, myelin, and CEF peptides as well as stimulating 


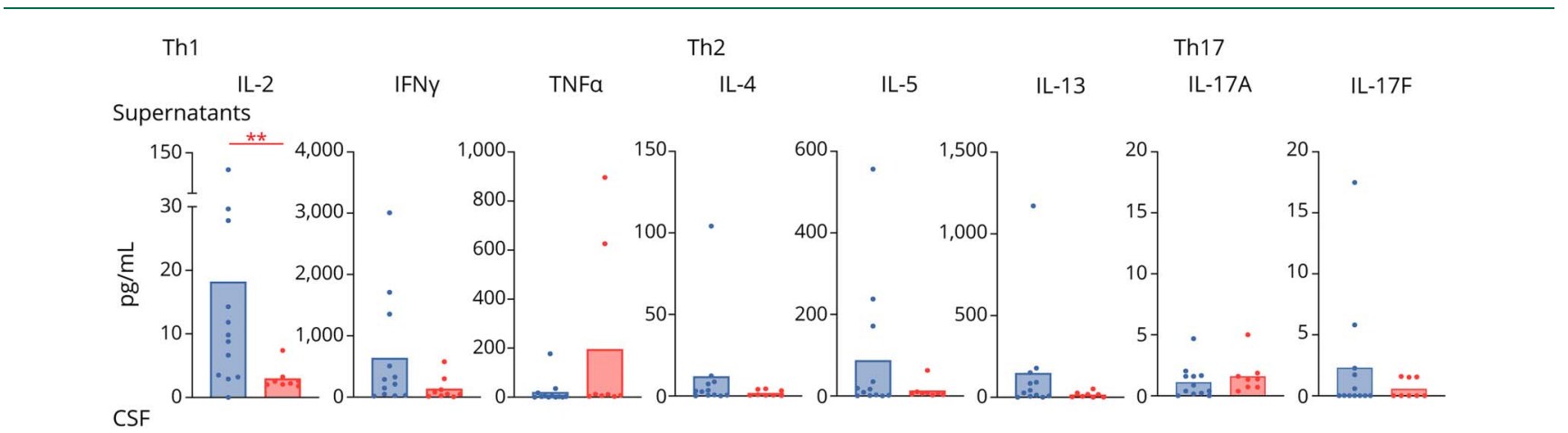

CSF

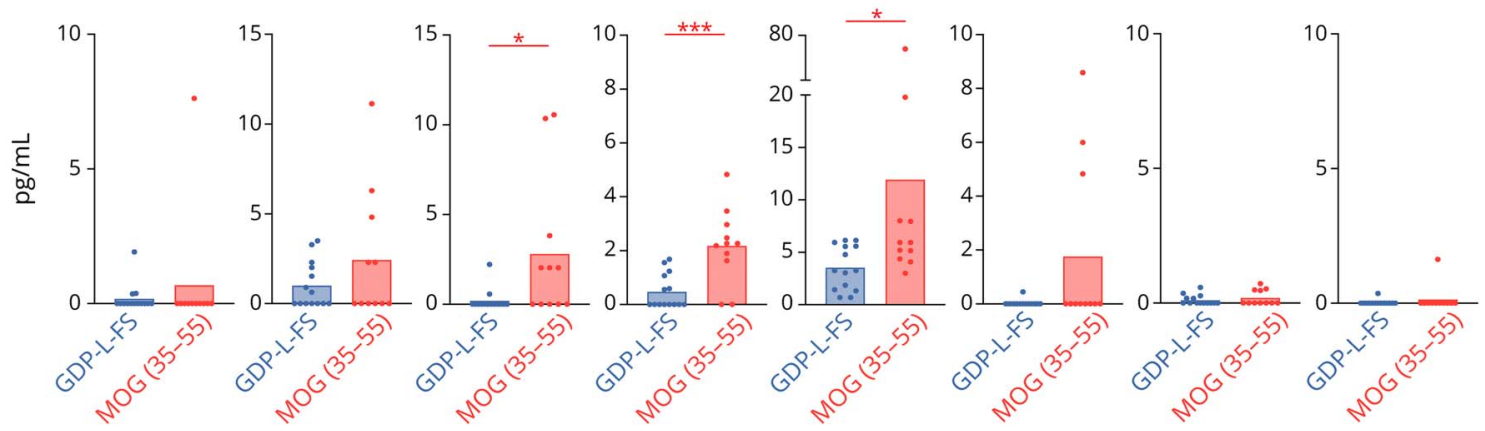

Th9

Th22

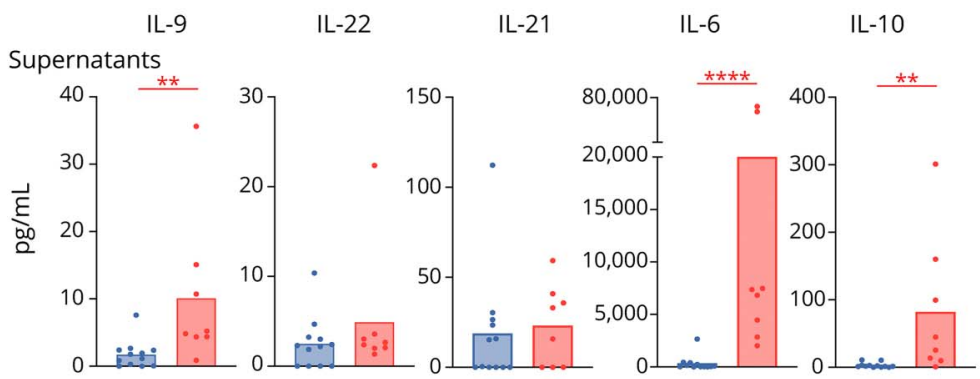

CSF

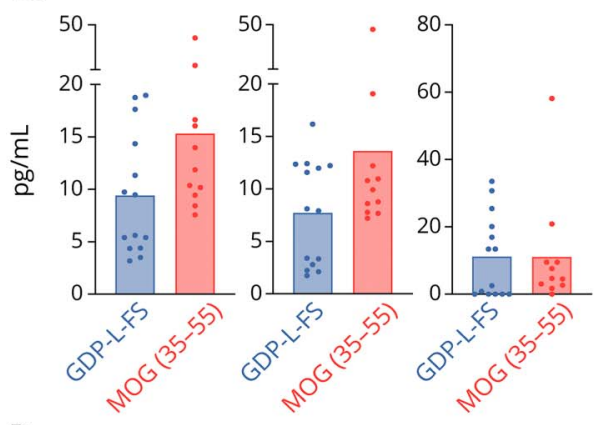

B Stimulation with: Antigen

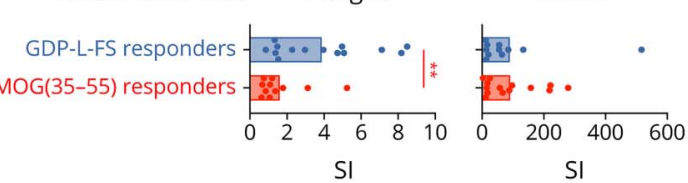

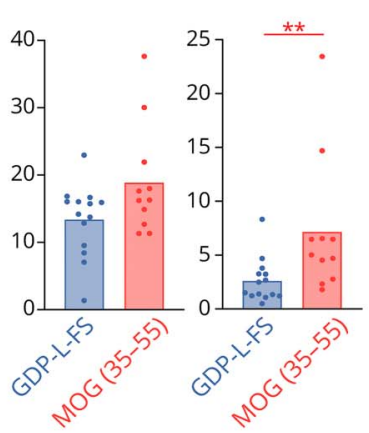

C. Naive $B$ cells $(C D 27-\lg D+)$

GDP-L-FS responders - 0 :

MOG(35-55) responders
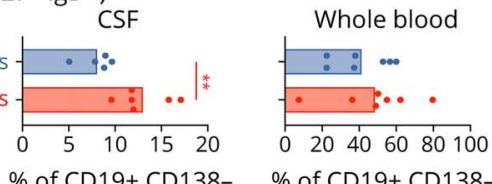

(A) Upper graphs, cytokines released by CSF-infiltrating CD4 ${ }^{+}$T cells from GDP-L-FS and MOG(35-55) responders after stimulation with specific peptides (GDPL-FS and MOG[35-55]) presented by autologous PBMCs. Four wells were pooled for each patient. Lower graphs, cytokines present in the CSF of GDP-L-FS and MOG(35-55) responders. Cytokines are expressed as pg/ml. (B) Proliferative responses of CSF-infiltrating CD4 ${ }^{+} \mathrm{T}$ cells from GDP-L-FS and MOG(35-55) responders after stimulation with the specific peptides presented by autologous PBMCs or anti-CD3, anti-CD28, and anti-CD2 stimulating beads. Proliferative responses are expressed as SI. (C) Frequencies of CSF-infiltrating and blood circulating naive (immunoglobulin D + CD27 $)$ B (CD19 ${ }^{+}$CD138 ${ }^{-}$) cells in GDP-L-FS and MOG(35-55) responders. Patient color code, GDP-L-FS responders (blue) and MOG(35-55)-responders (red). Each dot in the graphs corresponds to a single patient, and the bars show the mean. The Mann-Whitney test was used to compare GDP-L-FS and MOG(35-55) responders. Statistical significance ( ${ } p<$

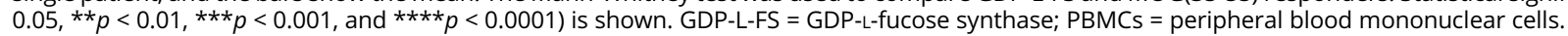



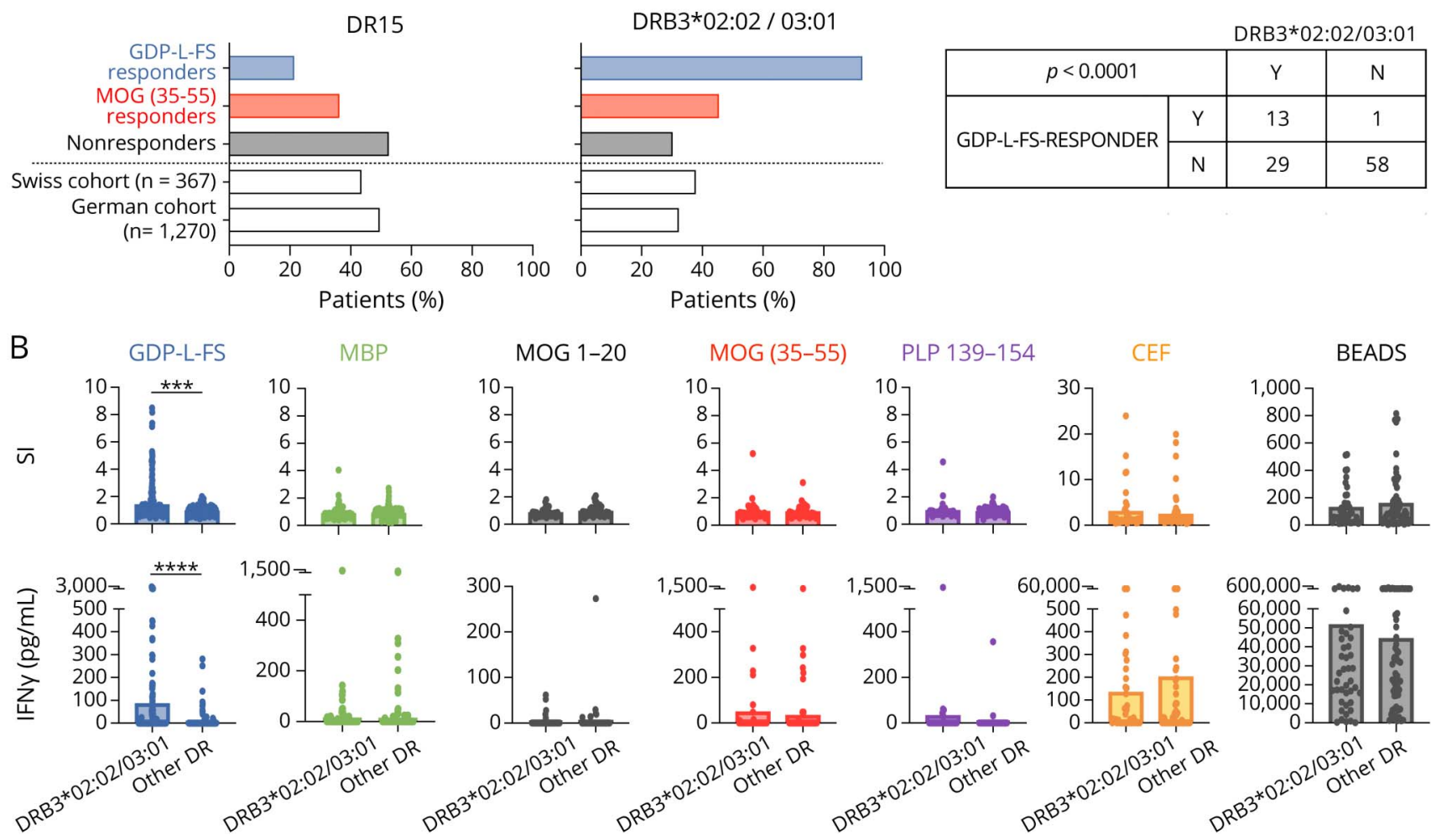

(A) Frequency of patients expressing the DR15 (left) and the DRB3*02:02/03:01 (right) genes in GDP-L-FS (blue), MOG(35-55) (red), and non- (black) responders as well as in two reference cohorts. Number of patients responding or not to GDP-L-FS and expressing ( $\mathrm{Y}$, yes) or not (N, not) the DRB3*02:02/03:01 genes and $p$ values for Fisher exact tests are shown. (B) CSF-infiltrating CD4 ${ }^{+}$T-cell responses (proliferation [SI] and IFN-y release) to GDP-L-FS (blue), MBP (green), MOG(1-20) (black), MOG(35-55) (red), PLP (violet), and CEF (orange) peptides and anti-CD2, anti-CD28, and anti-CD3 stimulatory beads (gray) from patients expressing or not the DRB3*02:02/03:01 genes. Each dot in the graphs corresponds to a single well. The Mann-Whitney test was used to compare patients expressing DRB3*02:02/ 03:01 and other DR. Statistical significance $\left(* \star \star p p<0.001\right.$ and $\left.{ }^{* \star \star \star} p<0.0001\right)$ is shown. GDP-L-FS $=$ GDP-L-fucose synthase; SI = single wells.

beads in patients expressing or not DRB3*02:02/03:01 alleles. Only the response to GDP-L-FS peptides, both by proliferation and IFN- $\gamma$ release, was significantly higher in $\mathrm{DRB}^{*} 02: 02 / 03$ : 01 patients than in patients expressing other HLA class II alleles.

\section{Demographic and Clinical Features of Patients With Different Specificity}

Demographic and clinical characteristics of GDP-L-FS, MOG(35-55), and nonresponder patients did not show significant differences (Table 2). Further characterization revealed a different seasonal distribution regarding the time point when the LP had been performed (Figure 6A), with a significant association between GDP-L-FS specificity and LP during winter/spring months $(\leq 0.0001$, Fisher exact test).

We also examined markers of compromised blood brain barrier permeability, disease activity, and several MRI parameters (Table 2). Although most of these markers were comparable between GDP-L-FS and MOG(35-55) responders, the semiautomated and blinded analysis of retrospectively collected brain MRI scans from 6 GDP-L-FS and 8 MOG(35-55) responders revealed statistically significant differences. The total number of contrast-enhancing T1 lesions and the total volume of FLAIR T2 lesions (Figure 6B) were significantly higher in GDP-L-FS compared with MOG(35-55) responders.

\section{Discussion}

This study represents the most comprehensive analysis of T-cell specificity performed in MS to date because it (1) analyzes CSF-infiltrating $\mathrm{CD}^{+} \mathrm{T}$ cells instead of PBMCs, (2) evaluates the reactivity not only against seven long-known immunodominant/encephalitogenic myelin peptides ${ }^{31}$ but also to five recently discovered immunodominant GDP-L-FS peptides, ${ }^{18}$ (3) uses as a readout IFN- $\gamma$ release in addition to proliferation based on the relevant role of Th1 cells in MS, ${ }^{5,18,23,31}$ and (4) is performed in a large cohort of 105 patients with MS. Proliferation confirmed a stronger reactivity against GDP-L-FS peptides, ${ }^{18}$ whereas IFN- $\gamma$ release identified MOG(35-55) as the strongest stimulatory peptide. IFN- $\gamma$ release identified more positive wells than proliferation and should be considered in future studies to avoid underestimating responses. The fact that only $27.6 \%$ of patients with MS showed positive responses suggests that we could have missed certain $\mathrm{T}$ cells by their too low frequencies or by not testing a broader range of cytokines, target antigens, or epitopes. ${ }^{40}$ In 
Table 2 Features of Patients With Multiple Sclerosis With Different Specificity

\begin{tabular}{|c|c|c|c|c|}
\hline \multicolumn{5}{|l|}{ Demographic and clinical features } \\
\hline & All & $\begin{array}{l}\text { GDP-L-FS } \\
\text { responders }\end{array}$ & $\begin{array}{l}\text { MOG(35-55) } \\
\text { responders }\end{array}$ & Nonresponders \\
\hline Number of patients & 105 & 14 & 11 & 76 \\
\hline Female/male ratio & 1.9 & 1.8 & 0.8 & 2.6 \\
\hline Age $(y)$ & $34.7 \pm 9.1$ & $39.1 \pm 11.2$ & $37.8 \pm 11.8$ & $34.7 \pm 9.2$ \\
\hline Age at onset (y) & $33.2 \pm 9.3$ & $37.1 \pm 10.3$ & $35.7 \pm 12.3$ & $33.1 \pm 8.7$ \\
\hline \multicolumn{5}{|l|}{ Clinical course } \\
\hline RIS/CIS (\%) & 13.3 & 14.3 & 9.1 & 15.8 \\
\hline RRMS (\%) & 78.1 & 78.6 & 81.8 & 76.3 \\
\hline PMS $^{\mathrm{a}}(\%)$ & 8.6 & 7.1 & 9.1 & 7.9 \\
\hline Disease duration (mo) & $28.6 \pm 51.9$ & $24.3 \pm 47.1$ & $24.6 \pm 31.4$ & $30.1 \pm 55.9$ \\
\hline CSF-specific OCB (\%) patients) & 94.2 & 100.0 & 100.0 & 97.4 \\
\hline \multicolumn{5}{|c|}{ Markers of altered BBB permeability, clinical activity, and brain MRI findings } \\
\hline & \multicolumn{2}{|r|}{$\begin{array}{l}\text { GDP-L-FS } \\
\text { responders }\end{array}$} & \multicolumn{2}{|l|}{$\begin{array}{l}\text { MOG(35-55) } \\
\text { responders }\end{array}$} \\
\hline CSF cell count (cells/uL) & \multicolumn{2}{|r|}{$7.07 \pm 8.87$} & $8.00 \pm 9.80$ & ns \\
\hline BBB damage $^{\mathbf{b}}$ (\% patients) & \multicolumn{2}{|r|}{35.70} & 36.36 & ns \\
\hline Time since last relapse $(d)$ & \multicolumn{2}{|r|}{$57.09 \pm 76.94$} & $132.20 \pm 220.04$ & ns \\
\hline Clinically active (\% patients) & \multicolumn{2}{|r|}{76.92} & 81.81 & ns \\
\hline Brain MRI active (\% patients) & \multicolumn{2}{|r|}{53.84} & 18.18 & ns \\
\hline \multicolumn{5}{|l|}{ Brain MRI semiautomatic analysis ${ }^{c}$} \\
\hline \multicolumn{5}{|l|}{ Volume absolute $(\mathrm{mL})$} \\
\hline Whole brain $(\mathrm{mL})$ & \multicolumn{2}{|r|}{$1,020.58 \pm 209.41$} & $1,124.69 \pm 100.99$ & ns \\
\hline Thalamus (mL) & \multicolumn{2}{|r|}{$10.57 \pm 1.56$} & $11.86 \pm 1.03$ & ns \\
\hline Gray matter $(\mathrm{mL})$ & \multicolumn{2}{|r|}{$630.05 \pm 125.44$} & $670.40 \pm 48.46$ & ns \\
\hline Gd contrast-enhancing T1 lesions (no) & \multicolumn{2}{|r|}{$1.50 \pm 1.04$} & $0.00 \pm 0.00$ & 0.001465 \\
\hline FLAIR T2 lesions (no) & \multicolumn{2}{|r|}{$25.83 \pm 25.74$} & $17.85 \pm 22.01$ & ns \\
\hline FLAIR T2 lesions total volume ( $\mathrm{mL})$ & \multicolumn{2}{|r|}{$4.19 \pm 3.17$} & $1.25 \pm 1.04$ & 0.048184 \\
\hline \multicolumn{5}{|c|}{$\begin{array}{l}\text { Abbreviations: CIS = clinically isolated syndrome; FLAIR = fluid-attenuated inversion recovery; GDP-L-FS = GDP-L-fucose synthase. OCB = oligoclonal band; RIS } \\
=\text { radiologic isolated syndrome; RRMS = relapsing remitting MS. } \\
\text { a PMS, progressive MS including primary progressive and secondary progressive MS. } \\
\text { b Blood brain barrier (BBB) damage (QALB-QNORM }>0 \text { ). } \\
\text { cBrain MRI semiautomatic analysis was performed in } 6 \text { GDP-L-FS and } 8 \text { MOG(35-55) responder patients from which brain MRIs at the time of LP were } \\
\text { available. } \\
\text { d } p \text { value, for the comparison of two groups of patients, we used the unpaired } t \text { test for normally distributed variables and the } U \text { test (Mann-Whitney) for non- } \\
\text { normally distributed variables. } \\
\text { Bold numbers indicated statistically significant differences. }\end{array}$} \\
\hline
\end{tabular}

addition, due to the relapsing-remitting nature of inflammation in MS, it is possible that we have missed certain $\mathrm{T}$ cells because antigen-specific $\mathrm{T}$ cells passage only transiently through the CSF and are not present at the time of the LP. The fact that only $38 \%$ of the patients showed $\mathrm{T}$-cell responses against strong viral/bacterial recall antigens supports this notion. Despite these limitations, we identified 14 GDP-L-FS, $4 \mathrm{MBP}$, and 11 MOG(35-55) responders.
GDP-L-FS responders frequently also recognized myelin peptides. The different sequences of the stimulatory GDP-L-FS and myelin peptides render it unlikely that cross-recognition by single TCCs is behind this association. Instead, a Th1/ cytotoxic response that results in the release of new peptides from damaged tissue and the activation of new autoreactive $\mathrm{T}$ cells, i.e., epitope spreading, ${ }^{41}$ might provide a more plausible explanation. Of interest, ex vivo immunophenotyping 
A
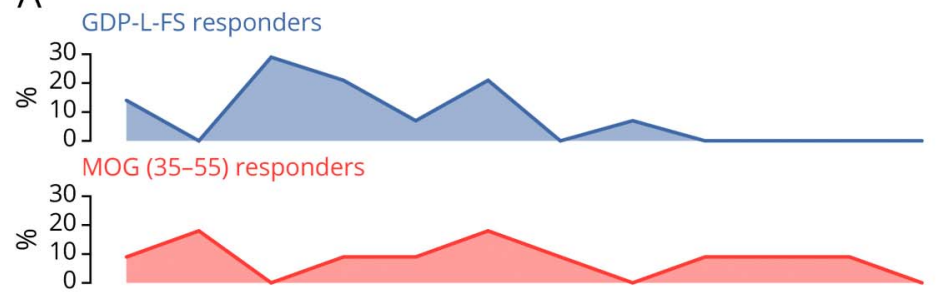
Nonresponders
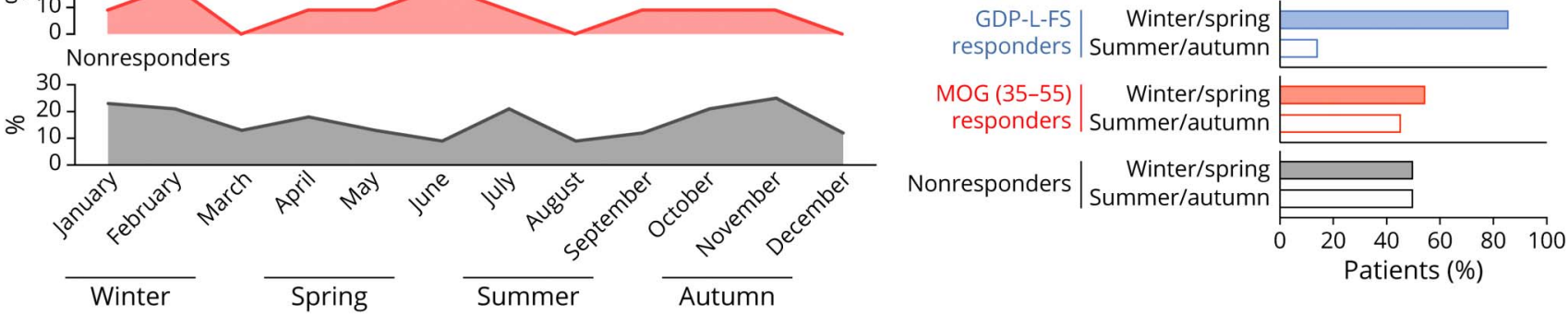

Gd-contrast enhancing T1 lesions

Total volume of FLAIR T2 lesions
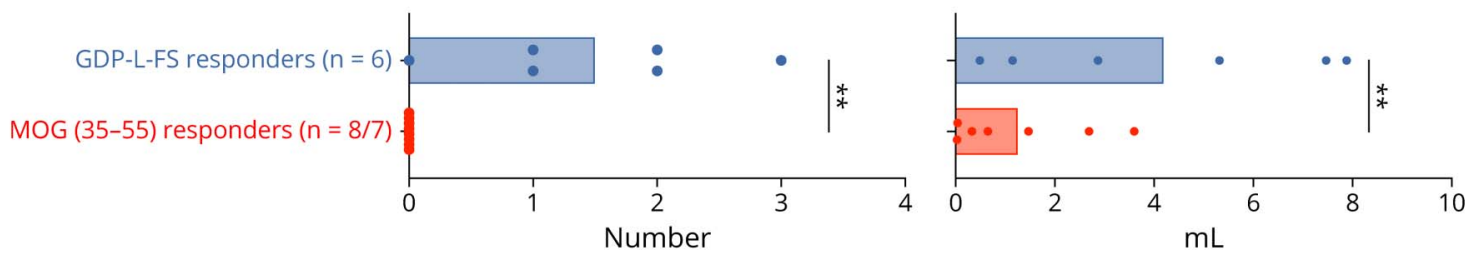

(A) Monthly distribution of LPs and frequency of samples obtained in winter/spring and summer/autumn in GDP-L-FS, MOG(35-55), and nonresponders. Red shadows show months with higher differences. Number of patients responding or not to GDP-L-FS in which LP was obtained in winter/spring (Y, yes) or not $(\mathrm{N}$, not) and $p$ values for Fisher exact tests are shown. (B) Number of total contrast-enhancing T1 lesions and total volume of flair T2 lesions (expressed in $\mathrm{mL}$ ) in GDP-L-FS- and MOG(35-55) responders. Each dot in the graphs corresponds to a single patient, and the bars show the mean. We used $t$ test for normally distributed variables to compare two groups of patients. Statistical significance ( $\star \star p<0.01$ ) is shown. GDP-L-FS $=$ GDP-L-fucose synthase.

demonstrated that $\mathrm{EM} \mathrm{CD} 27^{-} \mathrm{Th} 1 \mathrm{CD} 4^{+}$were significantly more abundant in the CSF and also peripheral blood of GDPL-FS-responders and that these cells in the blood expressed Th1- and cytotoxicity-associated genes. ${ }^{33}$ Whether this T-cell subset is enriched in GDP-L-FS-specific cells is still unknown and requires further investigation. Remarkably, high dimensional single cell analysis of $\mathrm{CD}^{+} \mathrm{T}$ cells from patients with rheumatoid arthritis (RA) identified an equivalent expanded EM $\mathrm{CD} 27^{-} \mathrm{CD} 4^{+} \mathrm{T}$-cell subset with a very similar transcriptome profile ${ }^{42}$ supporting a broader role of this cell subset in autoimmunity. Furthermore, both GDP-L-FS responders and patients with RA also have higher frequencies of TEMRA CD $28^{+} \mathrm{CD} 27^{-}$and $\mathrm{CD} 28^{-}$cells that have been associated with damage and clinical progression in RA. ${ }^{43}$

Cytokine analysis showed a relevant role of Th1 responses in GDP-L-FS responders and Th2 in MOG(35-55) responders. GDP-L-FS- and MOG(35-55)-specific cells did not release IL-17, a cytokine reported to be relevant in MS. ${ }^{44}$ Th17 and Th1* cells in patients with MS most likely have specificities that have not been included in this study. The higher intrathecal amounts of Th2 cytokines in MOG(35-55) responders suggest a role of humoral immunity in these patients. Accordingly, they showed higher frequencies of CSF-infiltrating naive B cells and higher CXCL13 levels. ${ }^{37}$
These patients also showed higher intrathecal amounts of IL10 that might regulate Th2 responses as it has been reported in allergy. ${ }^{45}$

GDP-L-FS-specific responses were associated with DRB3 $^{*}$ 02:02/03:01 alleles, confirming previous results, ${ }^{18}$ and were significantly more frequent in CSF samples obtained during winter and spring. Seasonality of infections as triggers of autoreactive $\mathrm{T}$ cells might underly this annual distribution, but gut microbiota dysbiosis due to seasonal changes in diet ${ }^{46}$ and vitamin $\mathrm{D}^{47}$ should also be considered because CSF-infiltrating $\mathrm{CD}^{+}{ }^{+} \mathrm{T}$ cells from GDP-L-FS responders cross-recognized homologous bacterial peptides. ${ }^{18}$ Finally, GDP-L-FS and MOG(35-55) responders also differed regarding MRI findings. It is remarkable that, despite the low number of patients from whom brain MRI scans were available at the time of LP, GDP-L-FS responders showed significantly higher numbers of contrast-enhancing $\mathrm{T} 1$ lesions and higher volumes of FLAIR T2 lesions, indicating higher inflammation and more extensive demyelination accordingly with more damaging immune responses.

In summary, our results reveal, an association between $\mathrm{T}$-cell specificity and features of disease heterogeneity in a $\mathrm{T}$ cell 
mediated autoimmune disease. A parallel association between disease severity and autoantibodies against citrullinated peptides is well described in patients with RA. ${ }^{48-50}$ The utility of this long-known association in the clinical management of patients with RA indicates the potential of our findings to improve clinical care and treatment decisions. In addition, our results might have important implications for personalized treatment approaches aiming at antigenspecific tolerance.

\section{Study Funding}

This work has been funded by European Research Council Advanced Grant (340733) (R.M.), Clinical Research Priority Program MS (CRPPMS) and (CRPP) PrecisionMS of the University Zurich (R.M., M.S., and A.L.), Clinical, Swiss National Science Foundation (Sinergia UnmetMS) (R.M. and M.S.) and the Swiss MS Society (R.M.).

\section{Disclosure}

All authors except R.M. and M.S. declare that they have no competing financial interests in the context of this work. R.M. and M.S. hold a patent on immunodominant proteins and fragments in autoimmune diseases (EP18180326.3; 2018). Go to Neurology.org/NN for full disclosures.

\section{Publication History}

Received by Neurology: Neuroimmunology \& Neuroinflammation April 26, 2021. Accepted in final form July 15, 2021.

\section{Appendix Authors}

\begin{tabular}{|c|c|c|}
\hline Name & Location & Contribution \\
\hline $\begin{array}{l}\text { Carolina } \\
\text { Cruciani, PhD }\end{array}$ & $\begin{array}{l}\text { Neuroimmunology and } \\
\text { MS Research (NIMS), } \\
\text { Department of Neurology, } \\
\text { University Hospital and } \\
\text { University Zurich, Zürich, } \\
\text { Switzerland }\end{array}$ & $\begin{array}{l}\text { Major role in the } \\
\text { acquisition of data and } \\
\text { analysis or interpretation } \\
\text { of data }\end{array}$ \\
\hline $\begin{array}{l}\text { Marco } \\
\text { Puthenparampil, } \\
\text { MD, PhD }\end{array}$ & $\begin{array}{l}\text { Neuroimmunology } \\
\text { and MS Research } \\
\text { (NIMS), Department } \\
\text { of Neurology, University } \\
\text { Hospital and University } \\
\text { Zurich, Zürich, } \\
\text { Switzerland; } \\
\text { Department of } \\
\text { Neuroscience DNS, } \\
\text { University-Hospital of } \\
\text { Padova, Padova, Italy }\end{array}$ & $\begin{array}{l}\text { Major role in the } \\
\text { acquisition of data and } \\
\text { analysis or interpretation } \\
\text { of data }\end{array}$ \\
\hline $\begin{array}{l}\text { Paula Tomas- } \\
\text { Ojer }\end{array}$ & $\begin{array}{l}\text { Neuroimmunology } \\
\text { and MS Research } \\
\text { (NIMS), Department of } \\
\text { Neurology, University } \\
\text { Hospital and University } \\
\text { Zurich, Zürich, Switzerland }\end{array}$ & $\begin{array}{l}\text { Major role in the } \\
\text { acquisition of data }\end{array}$ \\
\hline Ivan Jelcic, PhD & $\begin{array}{l}\text { Neuroimmunology } \\
\text { and MS Research } \\
\text { (NIMS), Department } \\
\text { of Neurology, } \\
\text { University Hospital } \\
\text { and University Zurich, } \\
\text { Zürich, Switzerland }\end{array}$ & $\begin{array}{l}\text { Major role in the } \\
\text { acquisition of data }\end{array}$ \\
\hline
\end{tabular}

Appendix (continued)

\begin{tabular}{|c|c|c|}
\hline Name & Location & Contribution \\
\hline $\begin{array}{l}\text { Maria Jose } \\
\text { Docampo, PhD }\end{array}$ & $\begin{array}{l}\text { Neuroimmunology and } \\
\text { MS Research (NIMS), } \\
\text { Department of Neurology, } \\
\text { University Hospital and } \\
\text { University Zurich, Zürich, } \\
\text { Switzerland }\end{array}$ & $\begin{array}{l}\text { Major role in the } \\
\text { acquisition of data }\end{array}$ \\
\hline $\begin{array}{l}\text { Raquel Planas, } \\
\text { PhD }\end{array}$ & $\begin{array}{l}\text { Neuroimmunology and } \\
\text { MS Research (NIMS), } \\
\text { Department of Neurology, } \\
\text { University Hospital and } \\
\text { University Zurich, Zürich, } \\
\text { Switzerland }\end{array}$ & $\begin{array}{l}\text { Major role in the } \\
\text { acquisition of data }\end{array}$ \\
\hline $\begin{array}{l}\text { Praveena } \\
\text { Manogaran, PhD }\end{array}$ & $\begin{array}{l}\text { Neuroimmunology and } \\
\text { MS Research (NIMS), } \\
\text { Department of Neurology, } \\
\text { University Hospital and } \\
\text { University Zurich, Zürich, } \\
\text { Switzerland }\end{array}$ & $\begin{array}{l}\text { Analysis or interpretation } \\
\text { of data }\end{array}$ \\
\hline Roland Opfer & $\begin{array}{l}\text { Jung Diagnostics GmbH, } \\
\text { HIP- Health Innovation } \\
\text { Port, Hamburg, Germany }\end{array}$ & $\begin{array}{l}\text { Analysis or interpretation } \\
\text { of data }\end{array}$ \\
\hline Carla Wicki, PhD & $\begin{array}{l}\text { Neuroimmunology and } \\
\text { MS Research (NIMS), } \\
\text { Department of Neurology, } \\
\text { University Hospital and } \\
\text { University Zurich, Zürich, } \\
\text { Switzerland; Department } \\
\text { of Health Sciences and } \\
\text { Technology, ETH Zurich, } \\
\text { Zurich, Switzerland }\end{array}$ & $\begin{array}{l}\text { Analysis or interpretation } \\
\text { of data }\end{array}$ \\
\hline $\begin{array}{l}\text { Markus Reindl, } \\
\text { PhD }\end{array}$ & $\begin{array}{l}\text { Clinical Department of } \\
\text { Neurology, Medical } \\
\text { University of Innsbruck, } \\
\text { Innsbruck, Austria }\end{array}$ & $\begin{array}{l}\text { Major role in the } \\
\text { acquisition of data }\end{array}$ \\
\hline $\begin{array}{l}\text { Ilijas Jelcic, MD, } \\
\text { PhD }\end{array}$ & $\begin{array}{l}\text { Neuroimmunology and } \\
\text { MS Research (NIMS), } \\
\text { Department of Neurology, } \\
\text { University Hospital and } \\
\text { University Zurich, Zürich, } \\
\text { Switzerland }\end{array}$ & $\begin{array}{l}\text { Analysis or interpretation } \\
\text { of data }\end{array}$ \\
\hline $\begin{array}{l}\text { Andreas } \\
\text { Lutterotti, MD }\end{array}$ & $\begin{array}{l}\text { Neuroimmunology and } \\
\text { MS Research (NIMS), } \\
\text { Department of Neurology, } \\
\text { University Hospital and } \\
\text { University Zurich, Zürich, } \\
\text { Switzerland }\end{array}$ & $\begin{array}{l}\text { Analysis or interpretation } \\
\text { of data }\end{array}$ \\
\hline $\begin{array}{l}\text { Roland Martin, } \\
\text { MD, PhD }\end{array}$ & $\begin{array}{l}\text { Neuroimmunology and } \\
\text { MS Research (NIMS), } \\
\text { Department of Neurology, } \\
\text { University Hospital and } \\
\text { University Zurich, Zürich, } \\
\text { Switzerland }\end{array}$ & $\begin{array}{l}\text { Drafting/revision of the } \\
\text { manuscript for content, } \\
\text { including medical writing } \\
\text { for content, and study } \\
\text { concept or design }\end{array}$ \\
\hline $\begin{array}{l}\text { Mireia Sospedra, } \\
\text { PhD }\end{array}$ & $\begin{array}{l}\text { Neuroimmunology and } \\
\text { MS Research (NIMS), } \\
\text { Department of Neurology, } \\
\text { University Hospital and } \\
\text { University Zurich, Zürich, } \\
\text { Switzerland }\end{array}$ & $\begin{array}{l}\text { Drafting/revision of the } \\
\text { manuscript for content, } \\
\text { including medical writing } \\
\text { for content; study concept } \\
\text { or design; and analysis or } \\
\text { interpretation of data }\end{array}$ \\
\hline
\end{tabular}

\section{References}

1. Sospedra M, Martin R. Immunology of multiple sclerosis. Annu Rev Immunol. 2005 23(1):683-747.

2. $\quad$ Sospedra M. B cells in multiple sclerosis. Curr Opin Neurol. 2018;31(3):256-262.

3. Fogdell-Hahn A, Ligers A, Gronning M, Hillert J, Olerup O. Multiple sclerosis: a modifying influence of HLA class I genes in an HLA class II associated autoimmune disease. Tissue Antigens. 2000;55(2):140-148. 
4. Friese MA, Jakobsen KB, Friis L, et al. Opposing effects of HLA class I molecules in tuning autoreactive CD8+ T cells in multiple sclerosis. Nat Med. 2008;14(11): 1227-1235.

5. Bielekova B, Goodwin B, Richert N, et al. Encephalitogenic potential of the myelin basic protein peptide (amino acids 83-99) in multiple sclerosis: results of a phase II clinical trial with an altered peptide ligand. Nat Med. 2000;6(10):1167-1175.

6. Miller SD, Karpus WJ. Experimental autoimmune encephalomyelitis in the mouse. Curr Protoc Immunol 2007; Chapter 15:Unit 15.1.

7. Weissert R. Actively induced experimental autoimmune encephalomyelitis in rats. Methods Mol Biol. 2016;1304:161-169.

8. International Multiple Sclerosis Genetics Consortium, Beecham AH, Patsopoulos NA, et al. Analysis of immune-related loci identifies 48 new susceptibility variants for multiple sclerosis. Nat Genet. Nov. 2013;45(11):1353-1360.

9. International Multiple Sclerosis Genetics Consortium. Multiple sclerosis genomic map implicates peripheral immune cells and microglia in susceptibility. Science. 2019; 365(6460):eaav7188.

10. Olsson T, Barcellos LF, Alfredsson L. Interactions between genetic, lifestyle and environmental risk factors for multiple sclerosis. Nat Rev Neurol. 2017;13(1):25-36.

11. Bjelobaba I, Begovic-Kupresanin V, Pekovic S, Lavrnja I. Animal models of multiple sclerosis: focus on experimental autoimmune encephalomyelitis. J Neurosci Res. 2018; 96(6):1021-1042.

12. McRae BL, Kennedy MK, Tan LJ, Dal Canto MC, Picha KS, Miller SD. Induction of active and adoptive relapsing experimental autoimmune encephalomyelitis (EAE) using an encephalitogenic epitope of proteolipid protein. J Neuroimmunol. 1992; 38(3):229-240

13. Manogaran P, Samardzija M, Schad AN, et al. Retinal pathology in experimental optic neuritis is characterized by retrograde degeneration and gliosis. Acta Neuropathol Commun. 2019;7(1):116.

14. Papadopoulos MC, Verkman AS. Aquaporin 4 and neuromyelitis optica. Lancet Neurol. 2012;11(6):535-544.

15. Reindl M, Waters P. Myelin oligodendrocyte glycoprotein antibodies in neurological disease. Nat Rev Neurol. 2019;15(2):89-102.

16. Dalmau J, Armangué $\mathrm{T}$, Planagumà $\mathrm{J}$, et al. An update on anti-NMDA receptor encephalitis for neurologists and psychiatrists: mechanisms and models. Lancet Neurol. 2019;18(11):1045-1057.

17. Hohlfeld R, Dornmair K, Meinl E, Wekerle H. The search for the target antigens of multiple sclerosis, part 1: autoreactive CD4+ T lymphocytes as pathogenic effectors and therapeutic targets. Lancet Neurol. 2016;15(2):198-209.

18. Planas R, Santos R, Tomas-Ojer P, et al. GDP-l-fucose synthase is a CD4(+) T cellspecific autoantigen in $\mathrm{DRB}^{*}$ 02:02 patients with multiple sclerosis. Sci Transl Med. 2018;10(462):eaat4301.

19. Polman $\mathrm{CH}$, Reingold SC, Banwell B, et al. Diagnostic criteria for multiple sclerosis: 2010 revisions to the McDonald criteria. Ann Neurol. 2011;69(2):292-302.

20. Puthenparampil M, Tomas-Ojer P, Hornemann T, et al. Altered CSF albumin quotient links peripheral inflammation and brain damage in MS. Neurol Neuroimmunol Neuroinflamm. 2021;8(2):e951.

21. Reiber H, Teut M, Pohl D, Rostasy KM, Hanefeld F. Paediatric and adult multiple sclerosis: age-related differences and time course of the neuroimmunological response in cerebrospinal fluid. Mult Scler. 2009;15(12):1466-1480.

22. Brodie T, Rothaeusler K, Sospedra M. OMIP-033: a comprehensive single step staining protocol for human T- and B-cell subsets. Cytometry A. 2016;89(7):629-632.

23. Jelcic I, Al Nimer F, Wang J, et al. Memory B cells activate brain-homing, autoreactive CD4(+) T cells in multiple sclerosis. Cell. 2018;175(1):85.e23-100.e23.

24. Bolger AM, Lohse M, Usadel B. Trimmomatic: a flexible trimmer for Illumina sequence data. Bioinformatics. 2014;30(15):2114-2120.

25. Bray NL, Pimentel H, Melsted P, Pachter L. Near-optimal probabilistic RNA-seq quantification. Nat Biotechnol. 2016;34(5):525-527.

26. Dobin A, Davis CA, Schlesinger F, et al. STAR: ultrafast universal RNA-seq aligner. Bioinformatics. 2013;29(1):15-21.

27. Robinson MD, McCarthy DJ, Smyth GK. edgeR: a Bioconductor package for differential expression analysis of digital gene expression data. Bioinformatics. 2010; 26(1):139-140
28. Reindl M, Schanda K, Woodhall M, et al. International multicenter examination of MOG antibody assays. Neurol Neuroimmunol Neuroinflamm. 2020;7(2):7.

29. Krüger J, Opfer R, Gessert N, et al. Fully automated longitudinal segmentation of new or enlarged multiple sclerosis lesions using 3D convolutional neural networks. Neuroimage Clin. 2020;28:102445.

30. Schippling S, Ostwaldt AC, Suppa P, et al. Global and regional annual brain volume loss rates in physiological aging. J Neurol. 2017;264(3):520-528.

31. Bielekova B, Sung MH, Kadom N, Simon R, McFarland H, Martin R. Expansion and functional relevance of high-avidity myelin-specific $\mathrm{CD} 4+\mathrm{T}$ cells in multiple sclerosis. J Immunol. 2004;172(6):3893-3904.

32. Hidalgo LG, Einecke G, Allanach K, Halloran PF. The transcriptome of human cytotoxic T cells: similarities and disparities among allostimulated CD4(+) CTL, CD8(+) CTL and NK cells. Am J Transplant. 2008;8(3):627-636.

33. Patil VS, Madrigal A, Schmiedel BJ, et al. Precursors of human CD4(+) cytotoxic $\mathrm{T}$ lymphocytes identified by single-cell transcriptome analysis. Sci Immunol. 2018; 3(19):eaan8664.

34. Pearce EL, Mullen AC, Martins GA, et al. Control of effector CD8+ T cell function by the transcription factor eomesodermin. Science. 2003;302(5647):1041-1043.

35. Eshima K, Chiba S, Suzuki H, et al. Ectopic expression of a T-box transcription factor, eomesodermin, renders CD4(+) Th cells cytotoxic by activating both perforin- and FasL-pathways. Immunol Lett 2012;144(1-2):7-15.

36. Kaneko K, Sato DK, Nakashima I, et al. CSF cytokine profile in MOG-IgG+ neurological disease is similar to AQP4-IgG+ NMOSD but distinct from MS: a crosssectional study and potential therapeutic implications. J Neurol Neurosurg Psychiatry. 2018;89(9):927-936.

37. Ansel KM, Ngo VN, Hyman PL, et al. A chemokine-driven positive feedback loop organizes lymphoid follicles. Nature 2000;406(6793):309-314.

38. Bonneh-Barkay D, Bissel SJ, Kofler J, Starkey A, Wang G, Wiley CA. Astrocyte and macrophage regulation of YKL-40 expression and cellular response in neuroinflammation. Brain Pathol. 2012;22(4):530-546.

39. Bergman J, Dring A, Zetterberg $\mathrm{H}$, et al. Neurofilament light in CSF and serum is a sensitive marker for axonal white matter injury in MS. Neurol Neuroimmunol Neuroinflamm. 2016;3(5):e271.

40. Varrin-Doyer M, Shetty A, Spencer CM, et al. MOG transmembrane and cytoplasmic domains contain highly stimulatory T-cell epitopes in MS. Neurol Neuroimmunol Neuroinflamm. 2014;1(2):e20.

41. Libbey JE, Cusick MF, Fujinami RS. Role of pathogens in multiple sclerosis. Int Rev Immunol. 2014;33(4):266-283.

42. Fonseka CY, Rao DA, Teslovich NC, et al. Mixed-effects association of single cells identifies an expanded effector CD4(+) T cell subset in rheumatoid arthritis. Sci Transl Med. 2018;10(463):eaaq0305.

43. Bauer ME. Accelerated immunosenescence in rheumatoid arthritis: impact on clinical progression. Immun Ageing. 2020;17:6.

44. Wagner CA, Roqué PJ, Goverman JM. Pathogenic T cell cytokines in multiple sclerosis. J Exp Med. 2020;217(1):e20190460.

45. Coomes SM, Kannan Y, Pelly VS, et al. CD4(+) Th2 cells are directly regulated by IL10 during allergic airway inflammation. Mucosal Immunol. 2017;10(1):150-161.

46. Davenport ER, Mizrahi-Man O, Michelini K, Barreiro LB, Ober C, Gilad Y. Seasonal variation in human gut microbiome composition. Plos One. 2014;9(3):e90731.

47. Soltys K, Stuchlikova M, Hlavaty T, et al. Seasonal changes of circulating 25hydroxyvitamin $\mathrm{D}$ correlate with the lower gut microbiome composition in inflammatory bowel disease patients. Sci Rep. 2020;10(1):6024.

48. Snir O, Widhe M, von Spee C, et al. Multiple antibody reactivities to citrullinated antigens in sera from patients with rheumatoid arthritis: association with HLA-DRB1 alleles. Ann Rheum Dis. 2009;68(5):736-743.

49. Lundberg K, Bengtsson C, Kharlamova N, et al. Genetic and environmental determinants for disease risk in subsets of rheumatoid arthritis defined by the anticitrullinated protein/peptide antibody fine specificity profile. Ann Rheum Dis. 2013; 72(5):652-658.

50. Boman A, Brink M, Lundquist A, et al. Antibodies against citrullinated peptides are associated with clinical and radiological outcomes in patients with early rheumatoid arthritis: a prospective longitudinal inception cohort study. RMD Open. 2019;5(2):e000946. 


\section{Neurology \\ Neuroimmunology \& Neuroinflammation}

\section{T-Cell Specificity Influences Disease Heterogeneity in Multiple Sclerosis}

Carolina Cruciani, Marco Puthenparampil, Paula Tomas-Ojer, et al.

Neurol Neuroimmunol Neuroinflamm 2021;8;

DOI 10.1212/NXI.0000000000001075

This information is current as of September 17, 2021

Updated Information \&

Services

References

Subspecialty Collections

Permissions \& Licensing

Reprints including high resolution figures, can be found at:

http://nn.neurology.org/content/8/6/e1075.full.html

This article cites 49 articles, 13 of which you can access for free at: http://nn.neurology.org/content/8/6/e1075.full.html\#\#ref-list-1

This article, along with others on similar topics, appears in the following collection(s):

All Immunology

http://nn.neurology.org//cgi/collection/all_immunology

Autoimmune diseases

http://nn.neurology.org//cgi/collection/autoimmune_diseases

Multiple sclerosis

http://nn.neurology.org//cgi/collection/multiple_sclerosis

Information about reproducing this article in parts (figures,tables) or in its entirety can be found online at:

http://nn.neurology.org/misc/about.xhtml\#permissions

Information about ordering reprints can be found online:

http://nn.neurology.org/misc/addir.xhtml\#reprintsus

Neurol Neuroimmunol Neuroinflamm is an official journal of the American Academy of Neurology.

Published since April 2014, it is an open-access, online-only, continuous publication journal. Copyright

Copyright (C) 2021 The Author(s). Published by Wolters Kluwer Health, Inc. on behalf of the American

Academy of Neurology.. All rights reserved. Online ISSN: 2332-7812.

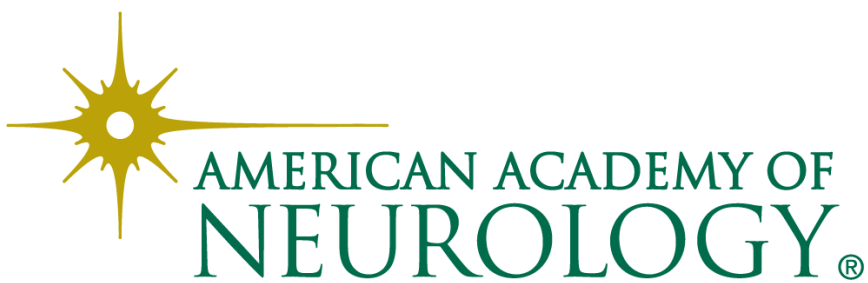

